\title{
TJETPPOTIS
}

\section{Moisture Relationships and Treatments in Revegetating Strip Mines in the Arid West}

\section{MORTON MAY}

Almost one-half of the surface area west of the Mississippi River (excluding Alaska and Hawaii) receives 15 inches or less annual precipitation, and about $20 \%$ of this vast area receives 10 inches or less yearly. It should be remembered that when referring to an area receiving, for example, 9 inches of precipitation annually, this is not the amount available for seed germination, seedling establishment, and growth. Sublimation of the precipitation received as snow may be as high as $80 \%$; surface runoff from bare surfaces and evaporation of low intensity and short duration rains must be subtracted from the total amount recorded; and the amount available to the vegetation may be as little as 4 or 5 inches in a 9-inch precipitation zone.

With increasing mining activity in the western states, the need for reclamation practices that emphasize arid land revegetation is essential. Almost without exception the biggest problem in reestablishing adequate stands of vegetation in these areas is the limited moisture available for plant growth; but even in areas receiving less than 10 inches of annual precipitation, ecologically stable stands of vegetative cover can be established on strip mined overburden.

Revegetation of stripped or open pit mined areas presents some unique moisture availability problems in comparison to normal range seeding programs. Elements and compounds that restrict normal root development frequently occur in the spoil associated with the mineral being mined. Examples of these would include aluminum or copper, the acids associated with uranium and coal mining, or salts of the trona and bentonite mining activities. In these situations where excessive phytotoxic material is incorporated in the spoil, the extraction of moisture by the plants for normal germination and growth becomes impossible unless adequate remedial treatments are employed.

The new overburden resulting from stripping activities has physical characteristics which further restrict moisture availability. The fresh spoil material is usually in large chunks, often quite hard and impervious to water. Although this "large rock surface phase" allows for maximum entrance of water into the overburden profile, water-holding capacity is minimal, and the precipitation received is percolated to depths beyond the root zone of the plants, resulting only in additional movement and instability of the spoil piles. Once the overburden has aged and the material has melted, or slaked, or in instances where the overburden is composed of finer textured material, the steep slopes (often at the angle of repose) resulting from normal drag-line removal, promote

The author is professor and head, Range Management Section, Plant Science Division, University of Wyoming, Laramie. maximum surface runoff. These steep angle or repose slopes are usually (but not always) shaped to gentler grades to meet mine reclamation requirements; and even here the massive scrapers, bull dozers, and haul trucks used to do the shaping job may confound the problem of water infiltration and percolation by compaction, forming extreme hard pans if sufficient fine textured material is present in the overburden surface.

Apparently, one of the less obvious moisture problems associated with newly developed spoil piles is that the overburden dumped on top of the piles may be taken from depths in excess of 200-300 feet, and is devoid of moisturc for all practical purposes. Time, as well as surface treatment, is needed to allow a subsurface moisture buildup that will sustain vegetative growth through the dry periods. Results published in the Journal of Range Management and other scientific publications relating to the history of range seeding trials have shown that often the only chance of success in establishing plant cover on our arid and semiarid ranges is on fallowed seed beds. In many of our strip mine reclamation programs we must also fallow our spoil piles, and take the time needed to obtain an adequate spoil moisture regime prior to seeding or planting. Unfortunately, many people are opposed to allowing "fallow time" for overburden piles. Public opinion dictates that we should revegetate the overburden as soon as possible, preferably while it is on its way up in the bucket. In addition, treating the spoil pile surface to reduce runoff or enhance infiltration and surface detention capacities by terracing, contour furrowing, or pitting is aesthetically displeasing in the eyes of many beholders as "not natural," or not in harmony with the surrounding terrain.

To overcome the moisture restrictions associated with mined land revegetation, several treatments other than those already mentioned have been employed, individually or in combination. Water suitable for irrigation is available in many of the mine pits or from wells that furnish water for various mining activities. This water can be used for initial stand establishment or to speed the succession process by growing mulch, or green manure crops, or other nurse crops to benefit the ultimate vegetation selected for the reclamation objectives.

Mulches of various types have been successfully used, including asphalt mulches, jute or excelsior netting, straw, sawdust, and chemical mulching materials that increase the moisture available for plant establishment, as well as acting to hold the seed and soil together in a more stable surface condition.

Throughout much of our arid west, the naturally occurring ingredients-snow and wind-can be harnessed to improve the limited moisture problem. The use of snow fencing as a 
sloping. The vegetation was predominately honey mesquite and tobosa grass (Hilaria mutica). Common broomweed was the dominant forb.

Honey mesquite trees were shredded monthly May 15, 1972, through October 15, 1972 (September was omitted) and individual stumps (and the area immediately surrounding the stump) were simultaneously sprayed with either the low volatile ester or the triethylamine salt f ormulation of $2,4,5-\mathrm{T}$ (2,4,5-Trichlorophenoxyacetic acid) or picloram plus 2,4,5-T (Tordon 225 Mixture $\left.^{1}\right)$. The chemicals were mixed according to the manufacturer's recommendations. One ounce of 2,4,5-T ester was dissolved in $1 \mathrm{oz}$ of diesel oil with water added to a volume of 1 gallon of solution. The 2,4,5-T amine formulation was mixed the same as the ester formulation except diesel was omitted. The Tordon 225 solution consisted of $2 \mathrm{oz}$ of Tordon 225 Mixture per gallon of water. All mixtures were equivalent to $3 \mathrm{lb}$ of herbicide per 100 gal of solution. A surfactant $\left(\right.$ Tronic $^{1}$ ) was added to each herbicide solution to approximate $0.02 \%$ of the total volume. Each treatment was replicated 15 times.

\title{
Results and Discussion
}

In the fall, 1973, a dense population of common broomweed had infested the study area (Fig. 1). However, the immediate area surrounding the stumps sprayed in

${ }^{1}$ Use of trade name does not constitute endorsement by the authors or Texas Tech University. It is used for the convenience of the reader.

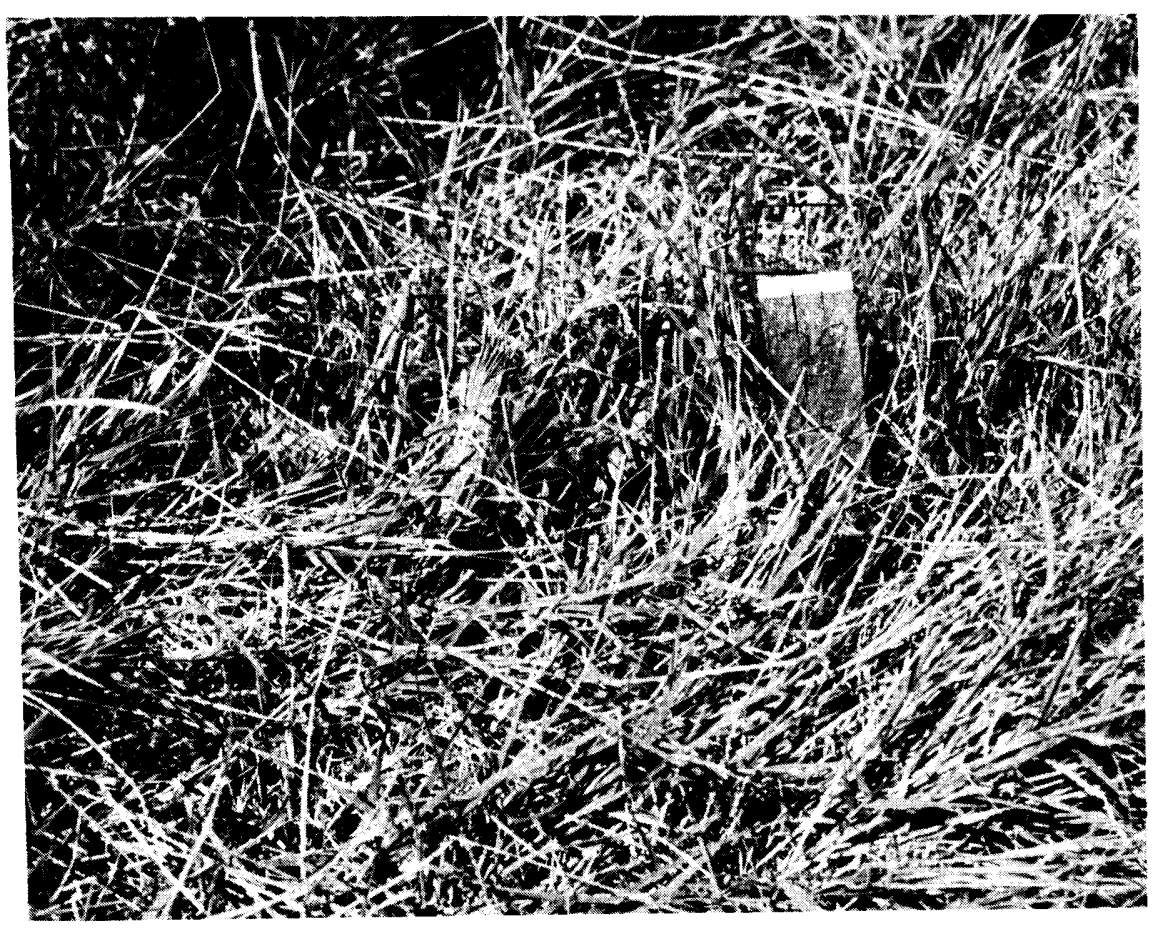

Fig. 2. Herbicidal control of common broomweed in the immediate area surrounding the stumps sprayed in October, 1972 (photograph taken in October, 1973).

October, 1972, with either 2,4,5-T ester, 2,4,5-T amine, or Tordon 225 Mixture was free of any broomweed plants (Fig. 2). Apparently, surface soil water content $(22 \%)$ and temperature were ideal for germination of the broomweed seed during fall, 1972. Therefore, fall application of herbicides effectively controlled common broomweed.

\section{Literature Cited}

Fisher, C. E., H. T. Wiedemann, J. P. Walter, C. H. Meadors, J. H. Brock, and B. T.
Cross. 1972. Brush control research on rangeland. Texas Agr. Exp. Sta. MP-1043. 18 p.

Hoffman, G. O. 1970. Noxious and poisonous range plant control. Texas Agr. Exp. Sta. L-598. 2 p.

Lofton, K. T., E. Blakely, and M. L. Dixon. 1972. Soil survey of Hardeman County, Texas. Soil Conserv. Serv., U.S. Dep. Agr. 25 p.

Scifres, C. J., R. R. Hahn, and J. H. Brock. 1971. Phenology and control of common broomweed on Texas rangelands. J. Range Manage. 24:370-373.

\section{Welcome to Omaha}

\author{
and the \\ 29th Annual Meeting of the \\ Society for Range Management
}

Resource Integration to Meet Society's Needs

February 16-20, 1976

Omaha Hilton Hotel

Omaha, Nebraska 
reclamation technique has several advantages over many other treatments. With proper placement and statistically controlled spacing of snow fences, a predictable amount of additional moisture can be accumulated. Up to 90 cubic feet of water per running foot of fence can be realized from a standard 4-foot snow fence and up to 1,100 cubic foot of water can be accumulated for each running foot using a snow fence 12 feet high. Snow melt behind these fences can be controlled, at least to a considerable degree, releasing water when and in amounts needed. The snow accumulation and subsequent water release helps to increase overburden slaking or melt. The additional moisture hastens leaching of soluble phytotoxic substances from the overburden surface, and can also serve to produce surface cracking, resulting in a desirable seedbed for broadcast seeding. Other possible benefits of snow fencing would include the accumulation of natural mulch and windblown seed, and versatility as either a permanent or temporary (and moveable) treatment that can eventually be replaced by "living" snow fences. Like their living counterparts "the shelterbelt" snow fences also serve to reduce evaporation loss from the surface during summer months, allowing more moisture to be available for vegetative response.

Naturally there are disadvantages connected with snow fencing on mined areas. General topography limits effectiveness, and not all sites are equally adapted to snow accumulation by snow fences. Repair and maintenance is a constant problem, especially on the steep slopes and on the shifting unstable overburden piles. Needless to say, this treatment is not effective in all parts of the west, but it is a treatment that can be the difference between success or failure in many areas to be reclaimed.

Since many states now have laws requiring that overburden must be topsoiled during the reclamation phase, some people have accepted this requirement as the total answer to all of our problems. Let me state here that I am not opposed to the idea of replacing topsoil on the spoil piles to be seeded. In many cases this treatment is a must to insure the success of reestablishing a plant cover. There are some problems, however, connected with topsoiling that we must face before we can continue toward successful reclamation of our mined rangelands.

First, it should be realized that the spoil or overburden material can be as good as or better than our native topsoil as media for plant growth.

Analyses, greenhouse studies, and field research show that the overburden, once it has melted and aged, can have a better base exchange capacity and better water holding capacity than the undisturbed azonal soils from the same area. Let me emphasize that this may not be the usual situation, but occasionally the raw overburden may have a high potential as a medium for plant growth and this potential must be evaluated prior to covering with topsoil. Several state laws now require that topsoil must be stockpiled from the areas to be mined and replaced or spread on the overburden after it has been shaped to conform with the surrounding topography. Have you ever stopped to consider where that topsoil will actually come from? The only soil available with sufficient depth to be stockpiled for later use, at least in much of our shallow soiled west, are those soils that have accumulated in the bottom sites-accumulated with high salt content, and now supporting only salt tolerant species such as greasewood or saltsage. We don't really need to confound an already difficult task by covering spoil piles with salt that won't leach out in our arid climates.

Another possible moisture problem related to topsoil applications may be apparent when we take a still closer look at our topsoil. Studies conducted in the mined areas in Wyoming, and areas that will be mined in the near future, show that the topsoil from the major vegetative types have large numbers of viable seeds incorporated in the soil surface. By taking soil samples from these areas (one square foot in size and $0-1$ " depths and 1-2" depth) and scattering this soil as a thin innoculate on flats of sterile sand in the greenhouse, the numbers of viable seeds present have been determined by simply counting those that germinate. Numbers of viable seed contained in these surface soil samples vary greatly between the vegetative types from which they were collected, as well as season of collecting. In excess of 850 viable seed can be found in the surface 1 inch of a 1 square foot sample of our native soil, and up to eleven hundred or more in the surface 2 inches of a 1 square foot area. Initially this looked like a great benefit-to be able to virtually "seed with topsoil." Seeding rates could be easily established and the species represented by the seed are "native" and automatically adapted to the local conditions. But the species that germinate are almost always those of secondary succession stages and can be highly competitive for moisture with the more desired species that may be seeded.

The salt and moisture competition problems can easily be avoided if we recognize that the problems can exist and realize that we must utilize a more selective process for obtaining the topsoil that will bc used, rather than simply taking what is most readily available.

Although moisture relationships present difficult problems to reclamation, the problems are not insurmountable, and productive objectives can be reached in reclaiming these arid and semiarid mined areas; but success can only be achieved through "proper planning."

To many people the real gut issue in strip mining is what the mined areas will look like, and can be used for, 30 to 40 years from now. As range managers we are charged with the responsibility of turning our rangelands over to the next generation in as good (or hopefully better) condition than we received them. This responsibility can be fulfilled, even in arid areas that have been stripped for mineral extraction, but only if we have proper and timely reclamation planning, based on sound research data. Simply hoping to get lucky in after-the-fact reclamation attempts is not sufficient as our contribution to the generations that follow.

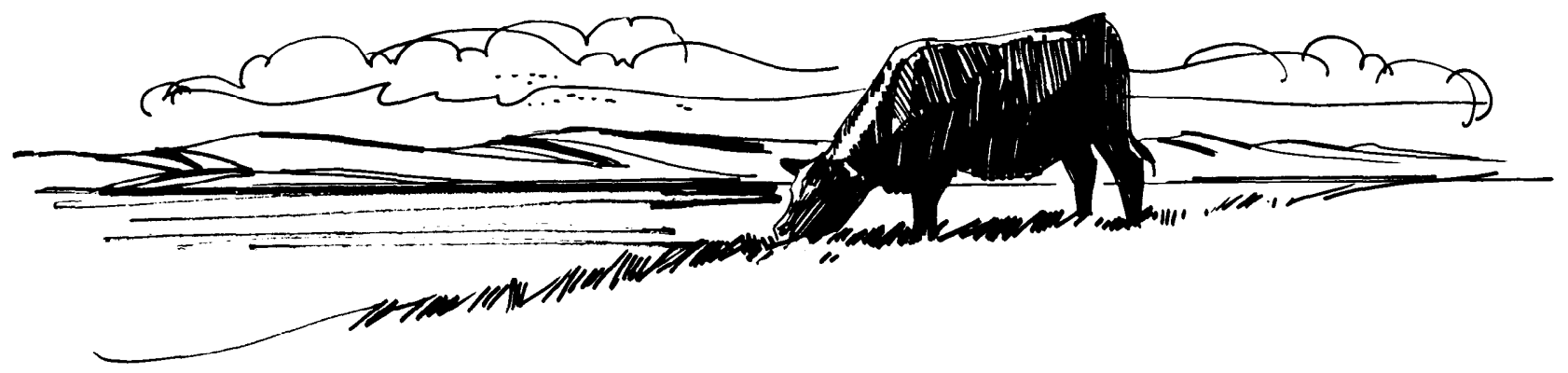

